\title{
ANALISIS FAKTOR-FAKTOR PENDUKUNG MINAT BACA MAHASISWA JURUSAN TARI DI PERPUSTAKAAN ISI SURAKARTA
}

\author{
Emi Tri Mulyani \\ Pustakawan Institut Seni Indonesia Surakarta \\ emitrimul123@gmail.com
}

\begin{abstract}
The rescarch entitled "Analysis of the supporting factors for reading interest in dance students in the library" contains about reading, reading in ferest factors and analysis of reading in ferest factors in Surakarta dance content students. The results of thes study used qualitative research methods with data obtained from written sources, observation and interviews. The theory used is a theory abaut reading and reading interest becouse it is a frame work for solving problems faced. The factors found in this study were the factors of purpose and benefits of reading, the availability of fasilies and infrastructure, the factor of teacher or lecturer, the availability of reading books, gender and the means of classmates. The results obtained from this study are that reading in terest of prospective dance graduates is very minimal or their lack of attention to reading books, research sources, and space in the library is sufficient and the problem of reading enthusiasts is a little making the library quiet several factors related to students majoring in dance to foster reading interest need to be strengthenet and encouraged so that libraries and reading centers in libraries become reference search destinations.
\end{abstract}

Keywords : Reading interest, Students, and Factors. 


\begin{abstract}
Abstrak
Penelitian yang berjudul "Analisis Faktor-Faktor Pendukung Minat Baca Mahasiswa Jurusan Tari di Perpustakaan" memuat tentang minat baca, membaca, faktor-faktor minat baca dan analisis faktor-faktor minat baca mahasiswa Jurusan Tari di ISI Surakarta. Hasil penelitian ini menggunakan metode penelitian kualitatif dengan data diperoleh dari sumber tertulis, observasi dan wawancara. Teori yang digunakan adalah teori tentang minat baca dan membaca karena merupakan kerangka dalam memecahkan masalah yang dihadapi. Faktor yang ditemukan dalam penelitian ini adalah faktor tujuan dan manfaat membaca, tersedianya sarana dan prasarana, faktor Guru atau Dosen, tersedianya buku bacaan, jenis kelamin, dan saran-saran teman sekelas. Hasil yang didapat dari penelitian ini adalah bahwa minat baca para calon sarjana tari sangat minim sekali dan kurangnya perhatian mereka pada membaca. Pengelolaan tentang buku bacaan, sumber penelitian, dan ruang di dalam perpustakaan sudah mencukupi dan masalah peminat baca sedikit menjadikan perpustakaan sepi pengunjung. Beberapa faktor yang terkait dengan mahasiswa Jurusan Tari untuk menumbuhkan minat baca perlu dipertebal dan digalakkan agar perpustakaan dan buku bacaan diperpustakaan menjadi destinasi pencari referensi.
\end{abstract}

Kata kunci : Minat baca, Mahasiswa, dan Faktor.

\title{
A. Pendahuluan
}

Membaca merupakan salah satu kegiatan dalam menambah pengetahuan. Pengetahuan yang dihasilkan dari membaca bukan hanya sebatas pada pengetahuan yang sempit tetapi luas. Pengetahuan merupakan sesuatu hal yang luas dan penting. Kegiatan membaca menjadi penting untuk meningkatkan pengetahuan yang dimiliki. Membaca merupakan salah satu kegiatan yang harus ditanamkan sejak dini, sehingga jika sudah memiliki minat baca pada usia dini maka jika sudah besar akan menjadi manusia yang berwawasan. 
Minat baca sekarang ini menjadi salah satu hal yang menjadi permasalahan saat ini bukan hanya pada anak-anak usia dini saja tetapi juga mahasiswa yang sudah menempuh pendidikan di perguruan tinggi juga memprihatinkan. Salah satu fenomena minat baca yang minim terjadi di perpustakaan jurusan tari ISI Surakarta. Minat menurut Winkel diartikan sebagai suatu kecenderungan yang menetap dalam subjek untuk tertarik pada bidang atau hal tertentu dan merasa senang pada bidang itu. ${ }^{1}$ Pendapat Winkel tersebut jika dikaitkan dengan pendapat Ginting yang mengartikan minat sebagai kecenderungan hati (keinginan, kesukaan) terhadap sesuatu semakin besar minat seseorang terhadap sesuatu perhatiannya lebih mudah tercurah pada hal tersebut. ${ }^{2}$ Kecenderungan minat sangat berkaitan dengan individu masing-masing dan takaran minat pada diri sendiri tergantung pada ketekatannya sehingga masing-masing indvidu akan memiliki besaran minat sendiri-sendiri.

Minat baca juga dipengaruhi oleh tekat masing-masing individu dalam menumbuhkan minatnya dalam menentukan kecenderungan pada bidang yang disukai. Problematika minat baca pada mahasiswa jurusan tari di ISI Surakarta juga sedikit sekali karena jurusan yang mereka pilih merupakan jurusan yang lebih banyak berkecimpung dalam bidang praktik dan sedikit sekali yang memiliki waktu berdiam diri dan membaca di dalam perpustakaan. Minat baca para calon sarjana tari tersebut sangat minim. Hal ini selaras dengan apa yang disampaikan Aminudin selaku alumni mahasiswa jurusan tari di ISI Surakarta bahwa manasiswa akan banyak berkesimpung di perpustakaan jika sudah menginjak mahasiswa atas dan akan menempuh ujian tugas akhir. ${ }^{3}$ Menanggapi fenomena tersebut penulis menjadi tertarik untuk mengungkap apa saja yang menjadi kendala dan apa saja yang menjadi minat baca para calon sarjana tari di perpustakaan.

1 WS Winkel, Psikologi Pendidikan dan Evaluasi Belajar (Jakarta: Gramedia, 1984), 30. 98.

${ }^{2}$ Cipta Ginting, Belajar di Perguruan Tinggi (Jakarta: Grasindo, 2003),

\footnotetext{
${ }^{3}$ Aminudin, Surakarta, 13 Maret 2018.
} 
Mengingat pentingnya referensi yang dibutuhkan mahasiswa tari dalam menempuh studi di ISI Surakarta sekiranya peran perpustakaan menjadi penting. Bukan saja sebagai tempat untuk mahasiswa tingkat akhir tetapi juga mahasiswa tingkat awal. Pentingnya perpustakaan tersebut sebagai sarana menambah referensi juga perlu ditunjang dengan ketersediaan buku atau referensi yang dibutuhkan harus dilengkapi sehingga penting perpustakaan diberikan sebanyak-banyaknya referensi agar mahasiswa tidak susah dalam mencari referensi kembali. Peranan perpustakaan sebagai jendela dunia akan sangat berguna dengan adanya proses melengkapi setiap referensi yang dibutuhkan mahasiswa.

Keterkaitan tentang referensi, mahasiswa, dan minat baca akan sangat berkaitan tergantung dengan perannya masing-masing. Peranan masing-masing inilah menjadi bahan yang nantinya akan digunakan untuk membedah faktor apa saja yang menjadi kendala dan bagaimana aplikasi faktor tersebut.

Penelitian yang digunakan adalah penelitian kualitatif dengan sumber data dari data tertulis, wawancara dan hasil pengamatan. Metode ini menerapkan sistem pengamatan yang mendalam, penulisan secara deskripsi dan data dianalisis menurut keterkaitan masing-masing. Adapun metode pengumpulan data yang dipakai adalah observasi, studi pustaka dan wawancara.

Observasi dilakukan sebagai awal menemukan data yaitu intensitas mahasiswa yang masuk dan membaca di perpustakaan, studi pustaka sebagai modal mencari referensi tentang minat baca, peran perpustakaan, dan data-data tentang masalah dalam penelitian ini, serta wawancara sebagai penguat dan penambah data yang didapat. Setelah dikumpulkan, data akan diintepretasi dan dianalisis menurut data yang didapatkan. 


\section{B. Pembahasan}

\section{Minat Baca Mahasiswa Jurusan Tari}

Sebelum membahas tentang minat baca perlu dikemukakan tentang peranan perpustakaan. Peranan perpustakaan menurut Sutarno dibagi menjadi 11 item yaitu : ${ }^{4}$

a. Perpustakaan merupakan sumber informasi pendidikan, penelitian, preservasi, dan pelestarian khasanah budaya, serta tempat rekreasi yang sehat.

b. Perpustakaan merupakan media atau jembatan yang berfungsi menghubungkan antara sumber sumber informasi dan ilmu pengetahuan.

c. Perpustakaan berperan sebagai sarana menumbuhkan minat baca.

d. Perpustakaan sebagai sarana menjalankan dan mengembangkan komunikasi antara sesama pemakai.

e. Perpustakan sebagai fasilitator, mediator, dan motivator.

f. Perpustakaan sebagai agen pembangunan, agen perubahan, dan agen kebudayaan.

g. Petugas perpustakaan dapat berperan sebagai pembimbing dan pemberi konsultasi.

h. Perpustakaan sebagai lembaga non formal.

i. Perpustakaan sebagai penghimpun dan melestarikan kolesi.

j. Perpustakaan berperan sebagai barometer kemajuan masyarakat.

k. Perpustakaan berperan dalam mengurangi dan mencegah kenakalan remaja.

Menelisik peranan perpustakaan ada salah satu peranan perpustakaan sebagai media untuk menumbuhkan minat baca. Minat sendiri merupakan unsur penting yang ikut menjalankan Semarang), 72.

${ }^{4}$ NS Sutarno, Perpustakaan dan Masyarakat (2006: Sagung Seto, 
tugas dan pekerjaan. Dalam bahasa sehari-hari dikenal istilah kesukaan yang artinya kurang lebih sama dengan minat. Menurut Munandir yang dikutip oleh Syufinur menyatakan bahwa kelancaran dan keberhasilan seseorang dalam menjalankan tugas makin besar peluangnya jika ada keterkaitanya akan pekerjaan yang dilakukan. ${ }^{5}$

Minat dapat ditarik garis besar memiliki 3 unsur yaitu 1) Kecenderungan yang mantap dalam diri subjek, 2) Rasa tertarik, suka, atau senang terhadap sesuatu tertentu, dan 3) Ketertarikan akan aktivitas tanpa terpaksa. ${ }^{6}$ Dengan demikian pengertian minat dapat dirumuskan sebagai suatu kecenderungan yang relatif mantap pada diri dan biasanya disertai dengan rasa ketertarikan untuk melakukan aktivitas dengan perasaan senang tanpa paksaan. ${ }^{7}$

Minat baca sangat berkaitan dengan individu yang akan menjalankan kesukaannya dalam membaca. Minat ini perlu adanya suatu dorongan yang nantinya akan penting dan menjadi salah satu motivasi dari dirinya untuk melaksanakan kesukaannya. Dalam kajian ini penting mengerti bagaimana peranan membaca dalam menumbuhkan minat seseorang. Salah satu kasus yang dihadapi adalah menumbuhkan minat baca di kalangan mahasiswa dengan jumlah mata kuliah praktik lebih besar daripada jumlah teori. Hal ini tenaga pikiran mahasiswa telah difokuskan pada praktik dan akan kesulitan mengambil waktu untuk menumbuhkan minat baca. Hal inilah yang menjadi penting sebagai pedoman dalam melaksanakan kegiatan menambah pengetahuan melalui media baca.

Dikaitkan dengan mahasiswa Jurusan Tari di ISI Surakarta minat baca sedikit sekali seperti yang dikatakan oleh Angga bahwa jarang ada teman-temannya satu kelas yang masuk ke

\footnotetext{
${ }^{5}$ Muhammad Syufinur, "Program Peningkatan Minat Baca Masyarakat oleh Perpustakaan Cinta Baca Medan Sunggal," 2017, 13.

6 Sukmawati, "Minat Baca Di Perpustakaan Pada Siswa SMP Negeri 1 Molawe Kabupaten Konawe Utara," Jurnal Penelitian Universitas Halu Oleo, 2016, http://sitedi.uho.ac.id/uploads_sitedi/G2G114044_sitedi_Jurnal\%20Tesis\%20 Sukmawati.pdf.

${ }^{7}$ Sukmawati.
} 
perpustakaan Jurusan Tari untuk membaca. ${ }^{8}$ Hal ini terkait dengan keseharian kegiatan mahasiswa jadwal kuliah sangat padat dan latihan praktik sampai malam sehingga waktu yang digunakan untuk ke perpustakaan atau membaca buku menjadi tidak ada. Melihat pentingnya referensi yang harus dimiliki oleh para mahasiswa Jurusan Tari maka perlunya membaca sebagai media penambah referensi.

Fenomena waktu yang kurang untuk menambah referensi dengan membaca akan menjadi kurangnya referensi pada mahasiswa sehingga peran perpustakaan sebagai penumbuh minat baca akan menjadi kurang efektif. Berbeda kasus dengan mahasiswa tingkat akhir yang banyak berkecimpung dengan dunia buku karena digunakan sebagai tambahan untuk menambah referensi tulisan tugas akhirnya. Banyak mahasiswa akhir yang datang ke perpustakaan untuk hanya meminjam buku yang dibutuhkan dan datang hanya mengerjakan tugas akhirnya. Hal ini tidak dilakukan pada semester-semester kecil yang menambah referensi utuk membaca tetapi fenomena ke perpustakaa terjadi karena adanya motif untuk mengerjakan tugas akhir saja. Kebiasaan ini menjadikan perpustakaan sebagai tempat musiman yang didatangi mahasiswa pada proses tugas akhir saja.

Setiap semester minimal terdapat tiga semester yang berbeda dan masing-masing terdapat dua sampai tiga kelas yang masing-masing kelas terdiri dari 35 mahasiswa dan yang setiap hari masuk ke perpustakaan minim sekali yaitu antara 3-5 orang saja. Keminiman pendatang di perpustakaan jurusan tari tidak lepas dari minat baca yang sedikit sekali dan sering tidak diperlukan oleh mahasiswa. Para mahasiswa datang untuk melihat referensi dalam mengerjakan tugas saja dan tanpa ada niatan untuk membaca secara intens. Kegiatan di kos-kosan juga hanya digunakan untuk berhenti istirahat saja dan tidak digunakan sebagai tempat membaca karena waktu pulang dari kampus sudah malam dan capek karena kuliah praktik sehingga hanya untuk istirahat saja.

${ }^{8}$ Angga, Surakarta, 17 April 2018. 


\section{Faktor-Faktor Minat Baca}

Membaca yaitu melihat serta memahami isi dari apa yang tertulis, dengan melisankan atau hanya menghafalkan dalam hati. ${ }^{9}$ Menurut Carter, membaca adalah proses mendapatkan arti, proses berpikir mengartikan dan menafsirkan arti, menerapkan ide-ide dari lambang. ${ }^{10}$ Suwaryono juga mengemukakan berbagai pendapat tentang membaca antara lain sebagai berikut:

a. Membaca adalah proses mendapatkan arti, proses berpikir mengartikan dan menafsirkan arti, menerapkan ide-ide dari lambang.

b. Membaca yang diartikan sebagai proses psikologi untuk menentukan arti kata-kata tertulis.

c. Membaca melibatkan penglihatan, gerak mata, pembicaraan batin, ingatan dan pengetahuan mengenai kata.

d. Membaca adalah aktivitas yang kompleks dengan mengarahkan sejumlah tindakan yang terpisahpisah yang meliputi: orang yang harus menggunakan pengertian dan khayalan, mengamati dan mengingatingat, kita tidak dapat membaca tanpa menggerakkan mata atau tanpa menggunakan pikiran kita. ${ }^{11}$

Pemahaman dan kecepatan efektif menjadi amat tergantung pada kecakapan dalam menjalankan setiap organ tubuh yang diperlukan untuk itu tergantung beberapa definisi membaca tersebut, Secara singkat menurut Tampubolon dapat diketahui bahwa hakekatnya membaca adalah kegiatan fisik dan mental untuk menemukan makna dari tulisan, walaupun dalam kegiatan itu terjadi proses pengenalan huruf-huruf. ${ }^{12}$

9 Tim Penyusun Kamus Pusat Pembinaan dan Pengembangan Bahasa Indonesia, Kamus Besar Bahasa Indonesia (Jakarta: Depdiknas, 2002), 18.

10 Suwaryono Wiryodijoyo, Membaca: Strategi, Pengantar, dan Tekniknya, Depdikbud, Jakarta (Jakarta: Depdikbud, 1989), 1.

${ }_{11}$ Wiryodijoyo, 1-2.

12 Prima Pantau Putri Santosa, "Pengaruh Penguasaan Kosakata terhadap Kemampuan Membaca Teks Persuasif Bahasa Inggris Siswa Kelas X 
Sementara menurut The Liang Gie yang dikutip Slameto menunjukkan ciri-ciri membaca yang efisien yaitu:

a. Mempunyai kebiasaan-kebiasaan baik dalam membaca.

b. Mengerti isi buku.

c. Masih ingat sebagian isi buku sehabis membaca.

d. Dapat membaca cepat. ${ }^{13}$

Membaca merupakan kegiatan yang sulit dilakukan dan menjenuhkan. Perlu adanya dorongan dalam diri masing-masing individu untuk menumbuhkan kecintaan tentang membaca sehingga akan menemukan dan mendapatkan wawasan yang luas. Modal utama seorang peneliti dari bidang apapun akan memerlukan referensi yang bayak untuk mengolah penelitiannya agar menjadi penelitian yang bagus. Referensi berupa kepustakaan akan terus digunakan, baik referensi berupa buku, laporan penelitian maupun jurnal-jurnal. Masing-masing individu memiliki kemampuan menangkap sesuatu yang dibaca secara berbedabeda. Penangkapan tentang objek yang dibaca akan dipengaruhi oleh pengalaman membaca yang dilakukan. Penambahan bahan bacaan menjadi penting dan bukan hanya bahan untuk objek yang dikerjakan tetapi objek-objek yang lainya.

Berhubungan dengan minat baca seseorang akan membutuhkan faktor-faktor yang berpengaruh. Faktor tersebut baik secara langsung maupun tidak langsung. Menurut Dawson dan Bamman yang dikutip oleh Rachman mengemukakan beberapa faktor yang mempengaruhi minat baca yaitu sebagai berikut $:^{14}$

a. Tujuan dan manfaat yang diperoleh setelah membaca, yaitu rasa aman, status dan kedudukan tertentu, kepuasan afektif dan kebebasan yang sesuai dengan kenyataan serta tingkat perkembanagan siswa, kebutuhan itu

SMK Negeri 2 Depok," Deiksis 9, no. 02 (2017): 173.

${ }_{13}$ Slameto, Belajar dan Faktor-faktor yang Mempengaruhinya (Jakarta: Rineka Cipta, 2010).

${ }_{14}$ Abd Rachman dkk., Minat Siswa SD di Jawa Timur (Jakarta: Pusat Pembinaan dan Pengembangan Bahasa Depdikbud, 1985), 6. 
berpengaruh pada pilihan dan minat baca masingmasing individu.

b. Tersedianya sarana buku bacaan keluarga merupakan salah satu pendorong terhadap pilihan bacaan dan minat baca siswa dan kemungkinan bahwa minat baca juga didorong oleh status sosial ekonomi keluarga.

c. Faktor guru atau dosen berperan dalam menumbuhkan minat baca setiap individu karena dengan informasi yang menarik tentang sebuah buku, maka siswa akan tertarik untuk membacanya dan sekaligus memperoleh sumber informasi.

d. Tersedianya sarana dan prasarana perpustakaan, jumlah dan ragam bacaan yang disenangi akan meningkatkan minat baca.

e. Faktor jenis kelamin juga berfungsi sebagai pendorong perwujudan pemilihan buku bacaan dan minat baca murid.

f. Saran-saran teman sekelas sebagai faktor eksternal dapat mendorong timbulnya minat baca murid.

Faktor yang mempengaruhi minat baca seseorang menjadi bagian penting dalam mengukur pengetahuan seseorang. Semakin banyak referensi yang dibaca akan mengakibatkan banyaknya modal untuk melakukan penelitian atau menjalankan kewajibannya dalam mengerjakan tugas-tugas kuliah. Modal tersebut akan banyak berguna dalam jenjang selanjutnya sehingga perlu adanya keseriusan dalam mencari referensi.

\section{Analisis Faktor-Faktor Minat Baca Mahasiswa Jurusan Tari}

Minat baca masing-masing individu selalu dikaitkan dengan kemauan atau dorongan yang menjembatani seseorang akan melaksanakan kemauannya. Berdasarkan dorongan tersebut akan menimbulkan kebiasaan yang berbeda sehingga minat baca akan muncul. Hal tersebut tidak terlepas dengan faktor yang mendukungnya, sehingga pentingnya terdapat suatu dorongan 
yang muncul. Salah satu peran perpustakaan sebagai media untuk menumbuhkan minat baca menjadi harus optimal. Adapun faktorfaktor yang mempengaruhi minat baca tersebut antara lain:

\section{a. Tujuan dan manfaat yang diperoleh setelah membaca}

Salah satu hal yang dilakukan adalah membaca untuk menemukan tujuan yang diperoleh. Sesuatu yang menjadi pokok dalam membaca adalah sebuah tujuan dan sebuah manfaat setelah melakukan kegiatan membaca. Kegiatan membaca biasanya berfungsi sebagai sarana mencari referensi dan mencari pengetahuan agar wawasan menjadi luas. Tujuan dari membaca adalah mencerdaskan diri dan menambah pengetahuan, sedangkan manfaatnya berupa dirinya menjadi lebih tahu, lebih mengerti, lebih peka, dan lebih pandai.

Berdasarkan pengamatan yang dilakukan setiap hari sebagai pustakawan di perpustakaan Jurusan Tari ISI Surakarta menemukan bahwa mahasiswa mencari referesi dan membaca memiliki tujuan dan nantinya akan bermanfaat. Menurut Aminudin, mahasiswa pascasarjana yang sering terlihat dan mengunjungi perpustakaan jurusan tari mengungkapkan bahwa tujuan masuk ke perpustakaan adalah mencari sumber buku, penelitian, ataupun jurnal-jurnal yang berkaitan dengan pembuatan tesis. ${ }^{15}$ Bukan itu saja yang ditemukan tetapi ada referensi lain yang didapat sehingga akan menemukan sesuatu yang baru dan menambah pengetahuan meskipun tidak sesuai dengan tesis dan biasanya sewaktu-waktu apa yang ditemukan muncul dan dibutuhkan.

Keterkaitan antara perpustakaan dan minat baca sangat erat untuk menentukan manfaat apa yang didapat, tetapi banyak pula mahasiswa jurusan tari yang hanya masuk ke perpustakaan hanya untuk sekedar bermain handphone, membuka laptop dan bermain internet. Perpustakaan ini ada pengunjungnya tetapi hanya digunakan sebagai media lain dan bukan untuk mencari sesuatu yang bertujuan dan nantinya akan bermanfaat. Salah satu

\footnotetext{
${ }^{15}$ Aminudin, wawancara.
} 
kekurangan mahasiswa jurusan tari adalah pengaturan waktu untuk menambah referensi yang dibutuhkan dan tersimpan dalam buku-buku di perpustakaan.

Setelah proses tugas akhir maka akan muncul kepanikan pada mahasiswa dan mencari referensi di perpustakaan hanya untuk dicari dan dikutip saja dan jarang untuk dimengerti. Kegiatan mengutip dan menyalin ini sering terjadi di perpustakaan. Sebagai pustakawan kurang lebih mengerti isian buku yang ada di perpustakaan. Hal ini menjadi penulis tahu bahwa banyak penelitian yang tulisanya hampir sama dan ada juga yang sama dan hanya diganti nama atau tempatnya saja. Kegiatan ini dilakukan dan tidak pernah terjadi pelanggaran dan jarang ada perbaikan jika terjadi kesamaan. Berkali-kali ditemukan tulisan yang sama pada penelitian yang berbeda. Hal ini tidak selaras dengan kajian ini yang mengutamakan tujuan dan manfaat dari membaca sehingga jika menjiplak akan berbeda dengan memahami.

\section{b. Tersedianya sarana buku bacaan atau referensi}

Faktor lain yang juga sangat penting adalah ketersediaan referensi yang dicari sehingga tidak kesusahan dalam mencari bahan. Ketersediaan dan kelengkapan referensi akan sangat penting sehingga perlu adanya kegiatan melengkapi koleksi nantinya akan berguna dan peminjam tidak mengalami kesulitan dalam mencari referensi. Bahan bacaan atau referensi juga setiap tahun ada penambahan dan melengkapi kekurangan, sehingga tetap ada yang datang untuk membaca dan mencari referensi.

Setiap satu semester selalu muncul buku-buku yang baru untuk menambah referensi sehingga tulisan-tulisan dalam buku tetap diperbaharui, sehingga tidak bosan dengan bacaan yang itu-itu saja. Keterbatasan referensi menjadi kemunduran pada perpustakaan karena kurang adanya minat baru pada mahasiswa untuk membaca dan menambah pengalamannya dari buku-buku bacaan. Menjadi penting jika dikaitkan dengan pengetahuan semakin hari semakin canggih dan rumit sehingga dengan adanya 
kerumitan dan kecanggihan akan memunculkan ilmu yang baru dan dengan adanya referensi akan berguna di lain waktu.

Setelah melakukan pengamatan mendalam dengan mendata referensi buku, laporan penelitian dan jurnal di perpustakaan tari kiranya perlu adanya penambahan bahan. Tidak lepas dengan perkembangan jaman dan ilmu pengetahuan, referensi sangat penting. Pernah suatu ketika buku yang dicari tidak ada maka mahasiswa akan kecewa dan meminjam ke perpustakaan lain sehingga akan menurunkan semangat pengunjung untuk menumbuhkan minat baca dan memahami isian dalam bahan.

\section{c. Faktor guru atau dosen}

Dorongan orang lain menjadi sangat penting dalam menjalankan sebuah kesukaan dan dorongan tersebut menjadi sebuah tugas. Tugas ini biasanya diemban oleh orang yang memberikan ilmu kepada seseorang dan menjadi sosok yang menjadi panutan dan tuntunan. Sosok tersebutlah yang nantinya mengarahkan ke dalam kesukaan membaca pada individu. Dorongan dapat berupa dorongan dari tugas atau untuk menambah referensi.

Kajian penelitian ini tidak terlepas dari peranan dosen sebagai media pendorong mahasiswa untuk aktif membaca dan menumbuhkan minat baca. Minat baca ini akan ditunjukan oleh dosen melalui banyak media dan bacaan. Dorongan tugas akan membuat mahasiswa semakin aktif dan kreatif karena akan berpengaruh dengan kebiasaan yang berbeda. Mahasiswa yang melaksanakan tugas akan memperhatikan tugasnya dan membaca buku yang nantinya akan menumbuhkan minat baca. Minat baca mahasiswa jika tidak didorong dengan tugas untuk mencari referensi maka mahasiswa tidak menjadi pintar dan berkembang kemampuannya.

Faktor dosen memberikan tugas kepada mahasiswa di Jurusan Tari Institut Seni Indonesia Surakarta untuk menemukan referensi dan membaca di perpustakaan belum terlihat secara 
signifikan. Kenapa demikian karena dapat dilihat pada hari-hari biasa saja mahasiswa yang datang dan membaca di perpustakaan relatif sedikit dan kurang sadar tempat yang dipakai perpustakaan. Tingkat kesadaran mahasiswa dengan adanya tugas dari dosen untuk membaca dan menambah referensi sangat minim, sehingga minat bacanya pun juga minim sekali. Faktor dosen ini sebenarnya menjadi alternatif menumbuhkan minat baca yang tinggi karena menuntun mahasiswa untuk berpikir dan mencari sumber-sumber untuk menjalakan segala perkuliahan sehingga akan punya bekal yang banyak. Kesadaran mahasiswa juga menjadi pertanyaan, karena kurang dapat dilihat perkembangan atau kemajuan penghuni perpustakaan jurusan tari dalam hal mencari referensi dan membaca.

Sekiranya model pembelajaran tentang perkuliahan dan dosen memberikan tugas seharusnya dicarikan metode yang gampang. Metode yang gampang seperti apa yang dilakukan akan berpengaruh pada dorongan mahasiswa dalam mengarungi perkuliahan. Proses pemberian tugas kepada mahasiswa untuk menjadikan mahasiswa menjadi tahu dan mengerti kurang memiliki tekanan sehingga mahasiswa akan kesulitan dalam tugas akhir karena memiliki pengetahuan yang minim. Peranan pembaca sangat berkaitan dengan pengetahuan yang dimiliki sehingga harus adanya dorongan dari dosen dengan kuat.

\section{d. Tersedianya sarana dan prasarana perpustakaan}

Faktor yang penting lagi adalah faktor dari perpustakaan itu sendiri bagaimana dalam mengolahnya mahasiswa menjadi tertarik untuk datang membaca dan mencari referensi. Perpustakaan sebagai tempat mencari referensi dan ilmu pengetahuan perlu adanya sarana prasarana penunjang yang lengkap. Hal ini tidak lepas dari kepentingan mahasiswa dalam mencari referensi agar mendapatkan ilmu dan pengetahuan harus berdasarkan sarana prasarana yang lengkap. Kelengkapan di perpustakaan juga diperlukan agar menjadi perpustakaan yang bisa digunakan sebagai tempat untuk mencari ilmu dan referensi. Modal untuk didatangi 
mahasiswa yang banyak harus menyediakan sarana prasarana yang lengkap dan nantinya mahasiswa tidak pergi dan mencari referensi di tempat lain.

Sarana prasarana yang ada di perpustakaan tari sebenarnya yang berhubungan dunia tari yaitu buku-buku tentang tari, tempat bacaan yang luas, ada rak dimana-mana, ada pustakawan, yang bisa berkomunikasi antar sesama. Sarana prasarana yang mendukung di perpustakaan tari ini menjadi hal yang penting dan dibutuhkan untuk menunjang kegiatan menumbuhkan minat baca dan mencari referensi. Sarana yang terdapat di perpustakaan antara lain adalah tempat untuk membaca, buku bacaan, komputer untuk mencari buku, dan ruangan ber-AC. Sarana dan prasarana tersebut yang akan digunakan dalam proses menumbuhkan minat baca dan tempat mencari referensi. Kenyamanan merupakan hal yang dicari untuk mendapatkan ketenangan dalam membaca dan mencari referensi, sehingga perpustakaan membutuhkan tempat yang nyaman dan aman.

Kekurangan yang ada di perpustakaan adalah ketidaknyamanan mahasiswa baik secara keadaan atau kesadaran. Keadaan dimana mahasiswa bertanya kepada pustakawan tetapi tidak menemukan jawaban dalam menemukan permasalahan yang dialami, semisal mencari buku, minta konsultasi dan berkomunikasi kurang lancar.

\section{e. Faktor jenis kelamin}

Jenis kelamin sebenarnya menjadi faktor kecil dalam menumbuhkan minat baca dan menambah referensi. Jenis kelamin adalah bawaan lahir dan tidak dapat ditiru oleh orang lain. Jenis kelamin akan mengakibatkan pilihan buku apa yang sekiranya akan menumbuhkan kesukaan akan membaca dan menambah referensi. Jenis kelamin juga menentukan jenis bacaan yang dipilih. Salah satu contohnya adalah pilihan akan bacaan laki-laki akan lebih ke dalam bentuk buku-buku tentang kekuatan, atau yang dapat membangun karakter dirinya, sedangkan untuk perempuan akan 
memilih buku-buku yang berkaitan dengan kefeminiman seorang perempuan dan akan menjadikan karakter putrinya.

Faktor jenis kelamin di Jurusan Tari ISI Surakarta akan sangat berbeda dengan di Universitas umum lainnya karena memiliki kajian yang khusus dalam dalam pelaksanaan dan pengembangan tugas akhirnya. Menelisik tulisan yang ada di perpustakaan Jurusan Tari akan mengenal berbagai macam buku tari dan kesenian serta prespektif kesenian dari ilmu lain. Faktor jenis kelamin tidak berpengaruh besar karena masing-masing memiliki kebutuhanya sendiri dan tidak ada perbedaan dalam memilih buku, karena buku yang dipilih selalu berkaitan dengan tari. Sebenarnya ini merupakan faktor internal yang ada karena menjadi penting dalam membentuk jati dirinya sebagai seorang.

Jumlah mahasiswa yang ada di Jurusan Tari juga mendukung tercapainya suatu bentuk pemilihan buku, tetapi berdasarkan pengamatan tidak terlalu terlihat perbedaan pemilihan buku karena dalam proses membaca dan menemukan referensi memiliki kesamaan objek yaitu tari dan buku penunjang selain tari hanya dipakai sewaktu sudah membutuhkan dan jika tidak membutuhkan maka juga tidak akan terbaca. Jenis buku yang lain dan tidak ada sangkut paut dengan tari akan terjadi ketegangan dalam dirinya sehingga akan mengganggu dalam mencari referensi.

\section{f. Saran teman mahasiswa}

Peranan teman menjadi penting untuk menumbuhkan minat membaca dan mencari referensi. Di perpustakaan jurusan tari, mahasiswa lebih banyak berinteraksi dengan teman-teman satu angkatan yang merekomendasikan buku bacaannya sehingga mahasiwa menjadi tertarik untuk memanfaatkan buku yang ada di perpustakaan. 


\section{Simpulan}

Berdasarkan hasil penelitian yang dilakukan oleh peneliti faktor-faktor yang mempengaruhi minat baca mahasiswa Jurusan Tari ISI Surakarta antara lain sebagai berikut:

1. Minat baca mahasiswa Jurusan Tari ISI Surakarta sangat minim sekali.

2. Kendala-kendala yang dihadapi dalam meningkatkan minat membaca mahasiswa jurusan tari ISI Surakarta yaitu tidak tersedianya waktu untuk datang ke perpustakaan dan membaca buku atau mencari referensi.

Dalam menumbuhkan minat baca akan ada hambatan, sehingga perlu adanya motivasi untuk menumbuhkan minat baca tersebut. Beberapa faktor yang dapat menumbuhkan minat baca antara lain tujuan dan manfaat membaca, tersedianya sarana dan prasarana, faktor dosen, tersedianya buku bacaan, jenis kelamin, dan saran teman mahasiswa. Kendala yang dihadapi oleh mahasiswa jurusan tari adalah minat baca mahasiswa minim dikarenakan mereka melakukan kuliah dan latihan sampai waktu pertengahan malam. Peranan perpustakaan dan para dosen akan sangat membantu dalam menumbuhkan minat baca mahasiswa jurusan tari ISI Surakarta. 


\section{DAFTAR PUSTAKA}

Aminudin. Surakarta, 13 Maret 2018.

Angga. Surakarta, 17 April 2018.

Ginting, Cipta. Belajar di Perguruan Tinggi. Jakarta: Grasindo, 2003.

Rachman, Abd dkk. Minat Siswa SD di Jawa Timur. Jakarta: Pusat Pembinaan dan Pengembangan Bahasa Depdikbud, 1985.

Santosa, Prima Pantau Putri. "Pengaruh Penguasaan Kosakata terhadap Kemampuan Membaca Teks Persuasif Bahasa Inggris Siswa Kelas X SMK Negeri 2 Depok.” Deiksis 9, no. 02 (2017): 170-81.

Slameto. Belajar dan Faktor-faktor yang Mempengaruhinya. Jakarta: Rineka Cipta, 2010.

Sukmawati. "Minat Baca Di Perpustakaan Pada Siswa SMP Negeri 1 Molawe Kabupaten Konawe Utara." Jurnal Penelitian Universitas Halu Oleo, 2016. http://sitedi.uho.ac.id/uploads_ sitedi/G2G114044_sitedi_Jurnal\%20Tesis\%20Sukmawati. pdf.

Sutarno, NS. Perpustakaan dan Masyarakat. 2006: Sagung Seto, Semarang.

Syufinur, Muhammad. "Program Peningkatan Minat Baca Masyarakat oleh Perpustakaan Cinta Baca Medan Sunggal," 2017.

Tim Penyusun Kamus Pusat Pembinaan dan Pengembangan Bahasa Indonesia. Kamus Besar Bahasa Indonesia. Jakarta: Depdiknas, 2002.

Winkel, WS. Psikologi Pendidikan dan Evaluasi Belajar. Jakarta: Gramedia, 1984.

Wiryodijoyo, Suwaryono. Membaca: Strategi, Pengantar, dan Tekniknya, Depdikbud, Jakarta. Jakarta: Depdikbud, 1989. 